doi: $10.1515 /$ scp-2016-0005

\title{
EFNISIEN'S TRICKSTER WILES: \\ MEANINGS, MOTIVES, AND MENTAL ILLNESS \\ IN THE SECOND BRANCH OF THE MABINOGI
}

\author{
NATASHA SUMNER
}

Harvard University

\begin{abstract}
This article examines the character of Efnisien in the Second Branch of the medieval Welsh collection of stories known as the Mabinogi. From the mid-nineteenth century until the present day, Efnisien has proved a troubling character for critical analysis. A preliminary examination shows that typologically, due to his antagonistic irrationality, he shares traits with both trickster and psychopathic figures. After highlighting these aspects of his characterisation, the article moves on to an analysis of Efnisien's function in the text. It is observed that Efnisien's irrationality is incongruous with the contingency and social relevance of the other characters' actions. He is shown to be the erratic, motivational force within catastrophe, and as such, to personify the inexplicable nature of such life-altering events and lend meaning to uncertain circumstances. From a Žižekian analytic perspective, he functions as a repository figure of ideological excess enabling the rationalization of incomprehensible trauma and securing the fictive narrative in which meaning is produced. Efnisien - trickster, psychopath, figure of excess - is thus shown to be vital to the production of meaning in the Second Branch of the Mabinogi.
\end{abstract}

Keywords: Mabinogi, Efnisien, medieval, Branwen, Second Branch, trickster, Žižek

Ardudwy Mental Health Centre

Patient: Ef Nyssyen
File \# P.4.5

The subject is prone to episodic malicious interactions with those around him. At these times, the subject experiences "ruthless [...] impulses towards aggressive action" accompanied by a disregard for others' feelings or safety. The subject consistently exhibits an "antagonistic relational pattern and antisocial behaviors" 
and a compulsive drive towards manipulative domination. It has therefore been determined that the subject presents a "psychopathic character structure."1

Even given the outrageous events of the Second Branch of the Mabinogi, it is surely a stretch to imagine a psychoanalytic clinic existing within the world of the tale. It may be an even greater leap of faith - and fantasy - to imagine the puzzling character, Efnisien, availing himself of such a resource. Surely he would do no such thing! Yet if he had, it is plausible that the above diagnosis could have been offered. I intend to show that the plausibility of such a diagnosis can contribute to our understanding not merely of Efnisien's erratic behaviour, but also of his character's indispensable function for the production of meaning in the tale. Typologically identifiable as both a trickster and a psychopath, Efnisien's antagonistic irrationality is, in fact, the vital fibre upon which meaning hinges. Examining the characterisation of Efnisien through first a Jungian archetypal, then a psychopathological, then a socio-historical, and finally a Žižekian lens, his crucial function for the story's audience will become apparent. For, as we will see, Efnisien figures the gap in the symbolic order of society; that is, he personifies the inexplicable nature of violence and trauma that resists symbolic interpretation in the social order, thus granting an audience the ability to rationalize apparent chaos.

From the time of Lady Charlotte Guest's translation of the tale in the midnineteenth century until the present day, Efnisien has proved a troubling character for critical analysis. In the late nineteenth century, Alfred Nutt (1882: 28) declared his conduct to be "arbitrary" and "without any adequate explanation." Following in the footsteps of Matthew Arnold (1867: 63-66), Nutt proceeded to remark that the Second Branch was undoubtedly "resultant of conflicting and ill-harmonized tradition" (1882: 28). In accordance with this line of thought, for the better part of a century Efnisien came to the fore only in the examination of his possible mythic derivation. ${ }^{2}$ Although such comparative

Characteristics of psychopathy described in Dougherty and West 2007: 183-86.

Among the most notable comparative mythological approaches is that of Proinsias Mac Cana (1958), who compared Efnisien to the Irish Bricriu. Mac Cana's aim in combing through Irish material for analogous folk motifs was to claim Irish origins for several incidents in the Mabinogi. Like W. J. Gruffydd before him, Mac Cana was unsatisfied with the tales' presentation and sought to uncover the original myths from which the tales were presumed to have derived - (re)created narratives which were often vastly different from the text as it has been preserved. Attempts at mythological reconstitution have largely been abandoned in more recent criticism in favour of considerations of the extant texts in the social and political contexts in which they were produced and experienced. In the past few decades, only Glenys Goetinck (1994) has adopted the reconstructive mythological vein of inquiry with her assertion that Efnisien and his allegorically opposed brother Nisien originated as versions of the IndoEuropean 'Divine Twins.' To support her theory she lists loosely analogous tales ranging from the Indian Vedas and Baltic song tradition to the Germanic Hengest legend and the stories 
studies have relatively little bearing on the issue of Efnisien's function in the text as we have it, I would like to draw attention to Georges Dumézil's (1948: 254-266) examination of Efnisien alongside the Irish Bricriu, the Iranian Syrdon, and the Scandinavian Loki. Dumézil suspected these characters' shared Indo-European provenance, but he also recognized their broader similarity to "le 'trickster' des Indiens de l'Amérique du Nord" and various other characters of traditional narratives that could be grouped under the 'trickster' archetype (257).

Among the pioneering scholars to examine the trickster were Daniel Brinton (1868:161-69; 1890) and Franz Boas (1898), who concentrated on delineating Native American trickster figures. ${ }^{3}$ After the publication of their initial studies, several scholars, including Dumézil, took up the task of exploring and explaining trickster figures and their relationships with one another and the narrative worlds they inhabit. The fruits of these labours ranged from purely typological analyses to psychological and even political interpretations. It was Carl Jung's (1959: 255-72) study that probably afforded these figures the most widespread repute. ${ }^{4}$ Perceiving the trickster as a manifestation of deeply buried psychic information, Jung proceeded to classify its character traits. While many of the traits he gathered together had been previously identified by those before him, his treatment of the trickster in connection with an innovative psychological theory received extensive notice. ${ }^{5}$

The characterisation of Efnisien agrees quite well with the basic trickster pattern outlined by Jung. The trickster, according to Jung (1959: 256), is notable primarily for his "unpredictable behaviour." This often emerges in the form of

about the Classical Dioscuri (Castor and Pollux/Polydeuces). In addition, Goetinck suggests that certain of Efnisien's traits may evidence the survival of pre-Indo-European, matrifocal societal values, in support of the female divinity and antagonistic to power figures representative of Indo-European androcentrism. The similarities between Efnisien/Nisien and characters of the 'Divine Twins' type have also been noted by Branwen Jarvis (2007: 67) in her examination of the degree to which Efnisien is a stock character, but Jarvis does not engage in mythological reconstitution.

3 Brinton used the word 'trickster' as a descriptive rather than categorical term. Boas used both 'trickster' and 'transformer' to describe the character type (Simmons 2005: 9-11).

$4 \quad$ Jung's examination of the trickster was initially published in1954 (trans. 1956) in Paul Radin's influential edition and study of Winnebago trickster tales. In 1959 it was included in the first English edition of Jung's collected works.

5 A number of scholars have examined the trickster since the publication of Jung's seminal work. Studies of trickster figures in the literature, folklore, and mythology of widely diverse cultures indicate that tricksters vary quite a bit in their characteristics, actions, and the consequences of those actions. Perhaps the most prominent conclusion that can be drawn is that the term 'trickster' is a blanket concept for a wide range of generally tricky behaviour leading to varying results. For a survey of trickster scholarship, see Simmons 2005: 11-32. For further examples of trickster characters and a list of common traits, see Babcock-Abrahams 1975: 158-160. 
"senseless orgies of destruction" not unlike those to which Efnisien finds himself prone. ${ }^{6}$ Efnisien's primary attribute is his ability to disturb the peace. We are prophetically told that he is gwr anagneuedus "[a] quarrelsome man" a man a barei ymlad y rwng y deu uroder, ban uei uwyaf yd ymgerynt [who would cause two of the most loving brothers to fight] (Thomson 1961: 3, 1; Davies 2007: 23, 22). In fact, Efnisien instigates conflict not between brothers, but rather between brothers-in-law and their followers, Bendigeidfran, king of Britain and Matholwch, king of Ireland. ${ }^{7}$ In each instance, conflict is prompted by a violent action that takes everyone aback.

When Efnisien learns that his half-sister, Branwen and Matholwch have been married without his knowledge or permission, he claims to be deeply insulted, even though there appears to have been no legal necessity for him to have been consulted. ${ }^{8}$ Moreover, there is no evidence that he was deliberately excluded from the negotiations. Since he was present at the arrival of Matholwch's ships when the Irish king's intentions were made clear, the only way he could have been unaware of the finalization of the arrangement is if he had deliberately removed himself from both the king's circle of counsel and the court for the entire duration of the exalted visitor's stay. His ignorance would then correspond to the trickster's removed nature, inhabiting the margins of society rather than the regular social sphere of legal rights and normative social customs (Jung 1959:

Jung viewed such trickster traits as "the reflection of an earlier, rudimentary stage of consciousness" (1959: 261) that all cultures experience before reaching "a higher level of consciousness" (266). Notions of evolutionary primitivism have long since been abandoned in the social sciences and I do not wish to evoke this particular aspect of Jung's classification of the trickster archetype.

7 See n.11 below for a consideration of Efnisien and his nominally opposite, but largely absent brother Nisien.

8 Whether there was any legal necessity for Efnisien to have been consulted is a debated point, but the bulk of the evidence falls on the negative side. As T. M. Charles-Edwards (1993: 179) indicates, the issue hinges on whether, as a uterine half-brother to Branwen, Efnisien was a member of the kinship legally implicated in selecting her husband. According to the Blegywryd redaction of the Welsh laws, "As a brother is entitled heir to his patrimony, so his sister is entitled heir to her endowment (through which she may get a wedded husband entitled to land), to wit, from her father or his heirs, if she abides by the advice of her parents and her co-heirs" (Jenkins 1986: 107). Efnisien is not actually part of the same agnatic kinship group as Branwen, Bendigeidfran, and Manawydan; he would not inherit patrimony from their father, Llŷr, but from his father, Euroswydd. He would therefore not be considered a co-heir of Branwen, and, by this reckoning, would not be among those on whose advice the selection of her husband would depend. While medieval Welsh law is not necessarily unified doctrine and the lack of clear provision for half-brothers still allows for some uncertainty ( $c f$. Ellis 1928: 127), the text of the story itself also seems to imply that a uterine half-brother need not be consulted. If Efnisien's approval were required, his offended reaction would not likely elicit such surprise. Nor would it need to be attributed to pa ryw wr "what sort of man" he is, but could rather be rationalized by the fact that he was legitimately wronged (Thomson 1961: 5; Davies 2007: 25). 
256). The vividly described violence of Efnisien's mutilation of Matholwch's horses does not merely surprise both kings; it evokes confusion and anger in its apparent irrationality, for no one could have foreseen Efnisien's objection to such a favourable marriage. ${ }^{9}$ Matholwch stresses that he finds the action eres "strange", ryued "strange", and reuedawt "a strange thing" under the circumstances, and Bendigeidfran can only rationalize it in reference to pa ryw wr "what sort of man" his half-brother is, implying that unpredictable antagonism is an inherent trait of Efnisien's personality (Thomson 1961: 4-5; Davies 2007: 2425).

After the mutilation of the horses, Efnisien disappears from the narrative for over two hundred lines (i.e. over forty percent of the text),${ }^{10}$ turning up next as part of Bendigeidfran's army which has arrived in Ireland to avenge Matholwch's mistreatment of Branwen. Evidencing his cunning, another trickster trait, Efnisien discerns and foils the Irish plot to ambush Bendigeidfran's men at the feast in celebration of the rulers' peace accord. Upon discovering the two hundred Irish troops hidden in hide bags, Efnisien brutally and suddenly crushes each of their skulls in turn. His violence here saves the unwitting Welsh host and might appear to be rationally guided by his cultural and/or familial allegiance, as it places the king of Britain in a position of power over the Irish king and restores Branwen's honour. But Efnisien's next

J. K. Bollard (1996b: 189) suggests that horse mutilation may have been a legitimate mode for responding to an offense, noting a passage in the Welsh laws pertaining to compensation for damage to a horse's tail, ear, or eye. In addition, Ifor Williams (1930: 171; $c f$. Mac Cana 1958: 158-59) has pointed out the removal of horses' lips and ears as a punishment in the Vita Sancti Cadoci and Dafydd Jenkins (1997: 73, 75) presents Welsh legal evidence for the symbolic significance of docking a horse's tail, as well as comparative English accounts of the docking of the tail as a form of rebuke or punishment. Alaric Hall (2001: 32) further calls attention to an incident in the Icelandic Hrólfs Saga Kraka referencing the cutting of horses' tails and forelocks as a punishment. These examples add weight to Bollard's theory. Yet the level of detail given in the horse mutilation incident in the Second Branch is grotesque in comparison. The exact placement and extent of each cut made by Efnisien are described and exceed the violence recorded in the examples. Efnisien cuts off not just the horses' tails, lips, and ears, but also their eyelids - which, incidentally, would contribute significantly to his goal of rendering the horses useless, given the likely result of keratitis succeeded by blindness (Thomson 1961: 3; Davies 2007: 24; Gilger 1983: 40). Also notable is the fact that unlike in any of the cited examples, Efnisien's brutal actions are described in progress, encouraging an audience to imagine the mutilation as it is taking place. While the act might well have been recognized as a codified response to a perceived insult, Efnisien's excessive, luridly specific, and viscerally present violence would seem to indicate that a strongly negative audience reaction was intended - likely the more so, given what little cause for insult there would appear to be. in his conciliatory offer to Matholwch) and line 331 in Thomson's edition (1961: 5, 13). When the mutilation of the horses is referenced again at lines 214-15, Efnisien is not named (8). The total length of the text is 483 lines. 
act of antagonism unsettles any such posited motivation. Just as peace has been achieved, and physically embodied in the son of the Irish king and his Welsh queen, Efnisien flings the boy into the fire where both he and the peace accord he symbolizes are destroyed. As Efnisien has calmly and cryptically declared, his intention was to commit [k]yflauan [anhebic] gan y tylwyth y wneuthur "an outrage [...] the household will never expect" (Thomson 1961: 14; Davies 2007: 31). This act cannot be rationalized by his shocked onlookers, and is bound to cause strife - which is precisely his goal. As the gwr anagneuedus "quarrelsome man," he is driven to provoke antagonism (Thomson 1961: 3; Davies 2007: 23). As the trickster, his antagonism is unpredictable, cunning and violent, and he is prone to disrupting both rulers' stratagems, regardless of whether peace or conflict is intended. In fact, it can be observed that up to this point in the text, Efnisien has only appeared during times of plan-making - the arrangement of Branwen's marriage, the Irish ambush plot, and the finalization of the subsequent Irish-British peace accord - and in each appearance, he has caused the sometimes tragic and always unreasonable thwarting of those plans.

Efnisien's characterisation as a disruptor of the peace assures us that he would find a way to initiate contention regardless of the situation. The initial introduction of Efnisien as the opposite to his brother Nisien, the gwas da "good lad" who is prone to making peace (Thomson 1961: 1; Davies 2007: 23), establishes audience expectations of Efnisien's future behaviour which are consistently upheld. ${ }^{11}$ Indeed, Nisien's and Efnisien's defining qualities, peace and hostility, are inherent in their names. W. J. Gruffydd (1928: 188n) and Ifor Williams (1930: 163) both point to the incorporation of the adjective efnys, meaning 'hostile, wrathful' or 'enemy, foe', in Efnisien's name and observe that

11 Nisien does not actually initiate the fleeting intervals of peace, however, and he is largely absent from this discordant narrative. In fact, Branwen and Bendigeidfran play more explicit peacemaking roles than Nisien in the instances in which peace is temporarily achieved: the period immediately following Branwen's and Matholwch's arrival in Ireland, the utopian congress of Bendigeidfran's surviving men with his severed head, and the head's subsequent protection of Britain from invasion. That Nisien does not live up to his explicit characterisation has led some critics to view him and Efnisien as vestiges of a mythological duo in which Nisien may have had more precedence in earlier versions of the tale. However, Proinsias Mac Cana (1958: 82-83) asserts that "there is no evidence whatever that Efnisien existed before the writing of Branwen," and that Nisien only turns up as the name of a Glamorgan saint. It is Mac Cana's contention that the notion of a good and a bad brother is evidence of Irish influence through the characters Bricriu and Sencha. Alaric Hall problematizes this theory in his examination of Nisien and Efnisien in comparison with Odinic brothers in Scandinavian and Germanic literatures. While Hall suggests a possible motif transfer, he is careful to affirm that he is not arguing for "the direct influence of Scandinavian or Middle High German narrative style on Branwen or vice versa - the evidence, though suggestive, is too slight" (2001: 44). For further discussion of the opposite brothers motif in the Second Branch, see Goetinck 1994, Rees 1975: 20-21, Jarvis 2007: 66-67, and Meulder 2008. 
the coinciding negative prefix $e f$ - indicates through word play what the narrator states openly - that Efnisien and Nisien are polar opposites (cf. Jarvis 2007: 67). More recently, Patrick Ford (1996: 114) highlighted the implicit meanings of these names in his labelling of "Mr Peace (Nisien) and Mr Un-Peace (Efnisien)." The fact that such outright, stock characterisation is reserved only for Efnisien contributes to the sense that he should be read as a character 'type'. And that type, as his cunning antagonism, his socially removed nature, and his drive to commit unpredictable acts indicates, is a version of the trickster.

From a Jungian perspective, the trickster is relevant to audiences because the character resonates with them psychologically. ${ }^{12}$ Modern Jungian analysts pursue such resonances in their investigations of human psychology. Indeed, it is interesting to note that from a psychoanalytic perspective, the typology of a trickster character like Efnisien bears a good deal of similarity to that of a psychopath. This correspondence has been gestured towards by Branwen Jarvis (2007: 71-76) and is worth exploring insofar as it serves to further illuminate Efnisien's characterisation. ${ }^{13}$ Were Efnisien undergoing psychoanalysis, his patient file might indeed resemble the fictionalized account produced in the epigraph to this article. Symptoms of psychopathy include the "ruthless [...] impulses towards aggressive action" and conniving, manipulative drive towards "domination" to which Efnisien is prone (Dougherty and West 2007: 185-86). ${ }^{14}$ Without a second thought, he is capable of brutally mutilating horses, crushing men's skulls, and burning his own nephew alive. While he is clearly aware of socially acceptable modes of behaviour and can "[play] well enough within the

Jung (1959: 3-4, cf. 256) contended that humanity's "collective unconscious" is populated by archetypes. In his view, the "conscious formulae" represented in stories (e.g. the trickster) both correspond with and derive from such unconscious archetypes. Jung's theory is now dated, and while I do not intend to engage deeply with it, I do wish to recognise the broad correlation between Jung's perspective that the trickster figure is psychologically relevant and my own reading of Efnisien.

13 Detailing Efnisien's creulondeb seicotig 'psychotic cruelty' (2007: 71), Jarvis posits that in this character can be seen an intentionally realistic portrayal of mental illness - a portrayal that she contends derives from the author's attempt to comprehend the psychology of a villain figure (76). Her analysis touches on many of the same behaviours explored with reference to trickster and psychopath typologies in this article. Additionally, she shows that the portrayal of Efnisien does not reflect common literary tropes of madness with which a medieval author would have been familiar (68-71).

It should be noted that according to this Jungian psychoanalytic approach, psychopathy and sociopathy are not recognized as separate disorders (Dougherty and West 2007: 184). According to analytical models which differentiate the two conditions, Efnisien's behaviour might appear similar to that of a sociopath. Alternatively, Jarvis (2007: 74) suggests a correspondence with the typology of paranoid schizophrenia in her assessment of Efnisien's behaviour from a different psychoanalytic perspective. For the purpose of this study, it is irrelevant which anachronistic designation for similarly symptomatic mental illnesses is most accurate. 
rules" to cooperate with others when he chooses (183), he does not feel obligated to adhere to those modes. In a diagnostic context, such behaviour is explained by a lack of internalization of the socially constructed notions of right and wrong that govern rationality. It is assumed that a psychopath feels no affective remorse for the unpredictable, violent actions to which (s)he is driven, but revels in the resultant feeling of power. ${ }^{15}$ Thus, and this is the key point, the "the psychopath is not immoral, but amoral"; (s)he is free from socially determined rules or laws and is therefore exempt from morality (Dougherty and West 2007: 187). Despite the considerable problems Efnisien's destructive actions cause, with only one exception (discussed below), they are not moralised in the story. Rather than resulting in moral censure or social consequences, his actions are simply accepted as the sort of erratic behaviour to be expected from the kind of character he is. His character has no overt moral lessons to teach, but instead serves another purpose, as I will argue towards the end of this article.

The purpose of this psychoanalytic exercise is not to establish the Second Branch of the Mabinogi as, in essence, the tragic tale of a destructive psychopath. Rather, the value of drawing out Efnisien's psychopathic tendencies as an inherent part of his trickster nature is that it forces us to realize the full extent of the irrationality and social confusion that Efnisien represents. Having performed this preliminary characterological study, it is now possible to move on to a more literary consideration of Efnisien's function in the text. This move away from categorical analysis is important because although he is a minor character, Efnisien's centrality to the narrative cannot be denied. Not only are we immediately introduced to him in the second sentence of the first paragraph, his irrational acts serve as stimuli, advancing the plot from one conflict to the next until the final resolution. What is more, a broader examination of the text will show that Efnisien's irrationality is incongruous with the contingency and social relevance of the other characters' actions. Most modern critics would agree that the world depicted in the story is not unsystematic, but a reflection of a highly ordered society - despite the chaotic disorder resulting from Efnisien's actions. ${ }^{16}$

Cf. Jarvis's (2007: 71) observation that Efnisien lacks [y] cysylltiad rhwng meddwl, teimlad a gweithred sy'n rheoli ymddygiad y gwastadbwyll 'the connection between thought, feeling, and action that governs the behaviour of the sane'.

16

The view that the Second Branch of the Mabinogi is a textually coherent, consciously produced narrative that reflects the social reality of medieval Wales is clearly in opposition to that of commentators like Arnold and Nutt, cited above, who saw it merely as a reservoir of fragmented, mythological memories. Among the earliest scholars to explore the contemporary relevance of the Mabinogi texts was E. J. Lloyd (1911a: 165), whose claim that "[t]he literature of a nation reflects its life and customs, embodies its main characteristics, and acts as a mirror to its history, social conditions, and religious conceptions" resembles the basic premise adopted by most modern scholars as their theoretical point de départ. See also Lloyd 1911b: 220-48. 
A consideration of the text with reference to its socio-historical context is essential to a more complete understanding of the function of Efnisien's character within the narrative.

Social information in the story is encoded in a number of legal references. Take, for instance, the regulation of feasts. At both the marriage and reconciliation feasts, seating arrangements are noted. The seat to which one was assigned was an important indication of one's status (Davies 2007: 229n; $c f$. Jenkins 1986: 7-8 and passim). Thus, in the Second Branch, the high status accorded to both Manawydan and Matholwch is stressed by their receipt of preferred seats next to Bendigeidfran, the king. (Efnisien is notably not seated or present at either well-ordered feast.) The type of hall for which such seating arrangements were designed was also ordained (Charles-Edwards 2000: 320). That the feasts in this text do not take place in a hall is a variation from the accepted norm. As such, the deviation is underscored for an audience that would find such a practise strange; we are told that feast-goers are not ymywn ty "in a house", as would have been typically presumed, namyn ymywn palleu "but in tents". This violation of normative practice serves to highlight the significance of the fact that ny angassei Uendigeituran eiryoet ymywn ty "Bendigeidfran had never been able to fit inside any house" (Thomson 1961: 3; Davies 2007: 23). In order for him to adhere to customs that are meant to take place indoors, special arrangements must be made. Adhering to such customs is crucial to the preservation of the social order. Although feasting in tents is unusual, the community makes the tents conform by arranging them ar ureint kyweirdeb yneuad "as if they were laying out a hall" (Thomson 1961: 5; Davies 2007: 25).

The terminology used in the text with regard to insults also reflects the medieval Welsh society in which it was produced. Efnisien's mutilation of Matholwch's horses reflects negatively on both Bendigeidfran and Matholwch, and the word used upon the initial discovery of the deed with regard to the grievances suffered by both men is gwaradwyd (Thomson 1961: 4) ${ }^{17}$ This is a loaded term. As Catherine McKenna (2007: 116) explains, "Gwaradwydd is more than an insulting act; it is dishonour, disgrace, ignominy and shame, a state of being that results from being exposed to ridicule and contempt." The word would have resonated greatly with a medieval Welsh audience deeply concerned with honour, which would certainly be the case if critics like McKenna are correct in assuming that the four branches of the Mabinogi were written primarily for a

17 On the other hand, the insult that Efnisien claims to have received is not termed gwaradwyd, but tremic, which refers to a slighting of one's legal rights or, more generally, disrespect (Thomson 1961: 3; Davies 2007: 24; Jenkins and Owen 1980: 219; Geiriadur Prifysgol Cymru). 
court audience. We later encounter the legal term sarahet (i.e. sarhaed) with reference to Efnisien's offense against Matholwch (Thomson 1961: 8). Sarhaed refers here to a serious insult that effectively blemishes or besmirches the honour of the kin. In compensation for such an insult, an honour-price is paid, upon receipt of which "shame (gwaradwydd) is removed, and the kin is shamefree (diwaradwydd)" (Owen 1980: 47). The honour-price given in the text to atone for this offense is llathen aryant a uo kyuref a'e uys bychan a chyhyt ac ef e hun, a chlawr eur kyflet a'y wyneb "a rod of silver as thick as [Matholwch's] little finger and as tall as himself, and a plate of gold as broad as his face," which, it turns out, is quite a hefty fine (Thomson 1961: 5; Davies 2007: 25). According to the example given in the Welsh laws, it is not much less than the honour-price for a king of Aberffraw, who could expect, among other things, "a rod of gold as tall as himself and as thick as his little finger, and a plate of gold as broad as his face, and as thick as the nail of a ploughman who has been a ploughman seven years" (Jenkins 1986: 5-6; qtd. in Davies 2007: 233n; cf. Bollard 1996b: 188). This location is significant in that it was traditionally recognized as the seat of power in Gwynedd, the kingdom that Bendigeidfran inhabits (Davies 1987: 217) although, since Bendigeidfran is described as the king of all Britain, perhaps his honour-price would be imagined by the audience as being significantly greater. At any rate, the amount of Matholwch's honour-price is sizeable and fitting for a king. So, too, is its substance, since gold plates as broad as a ruler's face, or silver or gold rods, are known as "symbols of royal honour" (Stacey 2000: 35). The payment of such a culturally symbolic honour-price is clearly meant to denote a legal resolution of the issue and to signal the impropriety of Matholwch's deferred dissatisfaction with this legal settlement.

Forms of punishment also have legal resonance and social significance. Specifically, the manifestly undeserved punishment of Branwen for Efnisien's crime appears even more offensive to a reader or listener familiar with (or immersed in) contemporary Welsh legal practices. We are told that Branwen's punishers act by gyrru Branwen o un ystauell ac ef, a'y chymell y bobi yn y llys, a pheri y'r kygyd, gwedy bei yn dryllyaw kic, dyuot idi a tharaw bonclust arnei beunyd "sending [her] from her husband's chamber, and forcing her to cook for the court; and they had the butcher come to her every day, after he had chopped up meat, and give her a box on the ear" (Thomson 1961:8; Davies 2007: 27-28). Married to Matholwch, Branwen is the queen of Ireland, and as such the specific behaviour that is most insulting to her is classified in the legal tracts. According to the Iorwerth redaction of Welsh laws, there were three ways in which insult (sarhaed) could be done to a queen, one of which was o'y tharau "by striking her" (Owen 1980: 46; cf. Jenkins 1986: 6); this, as we are told, was done beunyd 'daily'. Branwen's punishment would not only be insulting to a queen, however, since the act of alienating a woman from her husband was 
viewed as a particularly significant chastisement for any wife. According to Latin redactions of the Welsh laws, a woman's "expulsion from the marriage bed" (de lecto expelli) was considered one of the "three shames of a wife" (Tres [...] guarthrud mulieris) (Emanuel 1967: 242, cf. 494; Owen 1980: 51). The result of these harsh punishments is a negation of Branwen's elevated social status as a queen. Her perceived loss of honour is apparent in her declaration, $n y$ bwyf arglwydes "I am no "lady"; she rejects the designation on account of the amharch "dishonour" she has suffered (Thomson 1961: 10; Davies 2007: 29). Having been removed from the protection of her husband, her only course of action to rectify this loss of honour is to seek the aid of her kin. While the way in which she informs her family of her dishonourable predicament - training a bird to carry a message from Ireland back to Wales - reflects the imaginative, alternative reality of story, her decision to do so is socially and legally justified.

That the text of the Second Branch is coherent and socially relevant is further apparent in its reflection of aspects of the social organization of medieval Wales that may not necessarily all be codified in the laws. These encompass, most obviously, both the simple fact that the world portrayed is a social milieu populated by kings and their subjects, and the physical grounding of the opening sequence at a recognizable location, Harlech in Ardudwy. ${ }^{18}$ Furthermore, the narrator references customs such as the gathering of noblemen around a king, mal $y$ gwedei "as was appropriate", ${ }^{19}$ the inverting of a shield as a symbol of peace, the polite procedure taken when departing as a guest (that is, asking canhyat "permission" to leave), the honour of a queen's bestowal of gifts upon notable guests, ${ }^{20}$ the practice of fosterage, ${ }^{21}$ the regularity of ship traffic between Ireland and Wales, the appointment of stewards, ${ }^{22}$ and even the ceremonial investing of kingship (Thomson 1961: 1-11 ; Davies 2007: 22-30). It is the casual way in which the narrator refers to these customs that indicates that they were normal aspects of a medieval Welsh worldview. That they require little, if any,

18 That Harlech was the site of an Edwardian castle and prominent garrison in the late thirteenth century might contribute to a reading of Bendigeidfran's situation of a court there as a literary re-colonization of conquered territory, if not for the fact that the English castle was established as a result of the fall of Wales in 1282 (Davies 1987: 355). While the exact date of composition for the text is not known, McKenna (2007: 108) shows it to be prior to that: "The late-thirteenth-century Peniarth 6 fragments of the Four Branches $[\ldots]$ are evidence that the text had almost certainly been composed before the catastrophic annihilation of Welsh independence in 1282."

$19 C f$. the legal stipulation regarding the number and kind of people a king is entitled to have in his retinue (Jenkins 1986: 6).

20 Regarding queens' and married women's rights to gift-giving, see Owen 1980: 43-44.

21 Fosterage does not appear to have been commonly practised in Wales during the time of the composition and transmission of the laws (McAll 1980: 8), but would likely have been viewed as historically appropriate to the time in which the story is set.

22 Cf. Jenkins 1986: 12-14. 
explanation shows that a high level of audience familiarity is presumed. The wide range of such legal and social customs referenced served to render the world of the Second Branch of the Mabinogi familiar to its medieval audience. When considered largely apart from Efnisien's actions, the tale reflects a comprehensible image of the social realty of contemporary Welshmen and women. Efnisien's irrationality is the force that throws the world of the tale into disarray.

The disarray in the story is also likely to have resonated with a contemporary audience. As J. K. Bollard (1996a: 295) noted some years ago, the "series of losses and catastrophes" depicted in the Second Branch corresponds all too well with the historical reality of Wales, so that even in representations of crisis, the story effectively "provides the culture with a reflection of itself." The Mabinogi emerged during the increasingly violent period of the Norman Conquest - a time in which conflict was not confined to Welsh blood feuds, but as in the Second Branch, extended beyond the cenedl 'kindred' (292). To an audience facing this violent reality on a daily basis, the events of the story would have echoed the contemporary "losses, anxieties, and uncertainties of Wales" (McKenna 2007: 112). The cultural anxiety resultant from the Norman Conquest can be clearly perceived in Branwen's fear that llygru y wlat "the country would be laid waste" if peaceful negotiation between the two rulers were to fail (Thomson 1961: 12; Davies 2007: 30). That Branwen's fear is realized - both armies are utterly laid to waste in the great battle as a result of the chain of events motivated by Efnisien - symbolically represents the collective uncertainty of a not-yet-conquered Wales that the events then unfolding could just as completely destroy Welsh sovereignty, territory, and cultural values. As the erratic, motivational force within catastrophe, Efnisien personifies the inexplicable nature of such life-altering events. As has been recognised with regard to other trickster figures, he represents a device of social criticism - a "[manifestation] of the chaos on which order depends and over which it must reign supreme" (Koepping 1985: 193). He exists in order to lend meaning to uncertain circumstances that cannot be comprehended or rationalized in any other way.

Reiterated in terms of Lacanian psychoanalytic theory, as employed by Slavoj Žižek, Efnisien functions as a repository figure of ideological excess. In that the story exists within a coherent ideological system of meaning, it upholds what Žižek (1989: 123) refers to as the "fantasy" of a social order. This fantasy serves as both as "the frame through which we experience the world as consistent and meaningful" and "a screen concealing [its] inconsistency." The social fantasy acts much like a narrative in which the various elements are symbolically relevant and contingent upon one another. The narrative is reified through repetitive ritual acts that inscribe people "in the text of symbolic 
tradition," such as the laws and customs that effectively symbolize and fictionally recreate, day after day, medieval Welsh social reality (Žižek 1992: 23). But in order to preserve the coherence of this constructed narrative, the inevitable presence of inconsistency must be rationalized; antagonism must be explained in terms favourable to the persistence of the social narrative. This predicament is remedied by positing an 'Other' character, an Efnisien figure "introducing corruption into the sound social fabric" (Žižek 1989: 126). ${ }^{23}$ In taking the blame for the incomprehensible trauma that has erupted in the once peaceful (that is, consistent) social order, Efnisien masks the "irreducible gap between the Real and modes of its symbolization" (97). His motives are never entirely clear, for as a repository of excess he figures the "void" in meaning, simultaneously having no motives whatsoever and representing all the possible motives that could be invented to explain the inconsistency in the system (115). Efnisien's textual function, then, is to secure the fictive narrative in which meaning is produced.

There is still a missing link, if this analysis is to be accepted. It remains to be explored why, if Efnisien is such a figure of irrationality - a repository of ideological excess, he suffers a highly rational attack of conscience immediately preceding his death while destroying the cauldron of regeneration. On one hand, this event appears similar to his other instances of plan-breaking. Much like Efnisien's foiling of the ambush at the feast averts a conflict, his final act of destroying the cauldron unravels the Irish battle strategy, at the same time ensuring a Welsh victory. But, as several critics have noted, his remorse is entirely uncharacteristic. His declaration, Oy a Duw [...] guae ui uy mot yn achaws y'r wydwic honn o wyr Ynys y Kedyrn; a meuyl ymi [...] ony cheissaf $i$ waret rac hynn "Oh God [...] woe is me that I am the cause of this mountain of the men of the Island of the Mighty; and shame on me [...] unless I try to save them from this" (Thomson 1961: 14; Davies 2007: 32), is the only emotion he voices and it is coupled with the Christian motif of the penitent sinner. Although the story is set in an imagined, pre-Christian Britain, the fact that the society portrayed is reflective of a medieval Welsh milieu establishes the operation of a Christian ideology (Bollard 1996a: 278-9). The religiosity of Efnisien's outburst underscores this fact. As a narrative device, Efnisien has functioned up to this point as the 'Other' that corrupts the social fabric. Through his repentance he is drawn back into the ideologically-Christian social order,

23 Žižek (1989: 122, 126-8) uses the figure of 'the Jew' to signify what is generally referred to as 'the Other.' While I have substituted the more conventional expression, it should be borne in mind that for Žižek, 'the Other' (used interchangeably with 'the big Other') refers to the symbolic order itself, whereas 'the Jew' is posited as the excess in that symbolic order, "the immanent antagonistic character of the system," displaced from and preserving the social fantasy. 
but only to be eliminated in his consequent death. Viewed in this way, this incident can be read as the structurally necessary point at which Efnisien negates his irrational trickster nature by ultimately submitting to narrative rationality. ${ }^{24}$ In order for the narrative to aid the audience to come to terms with their fears of societal collapse, the elimination of Efnisien's violent unpredictability needs to happen; the uncertainty that he figures has to be perceived as being capable of resolution.

The events that follow Efnisien's demise support my reading of the text and his function in it. Both in Christian ideology and more generally as the foundational purpose of the social fantasy, there is a drive towards the achievement of a utopian state through the elimination of inconsistency. As Žižek (1992: 126) puts it, "the stake of social-ideological fantasy is to construct a vision of society which does exist, a society which is not split by an antagonistic division, a society in which the relation between its parts is organic, complementary." The removal of the trickster figure from the narrative enables the fulfilment of Bendigeidfran's final plan, for it is not impeded by Efnisien's unpredictable trickster wiles. Here we see the realization of a posited social utopia as the survivors of Bendigeidfran's military retinue live in undisturbed peace in idealistic locales with his conversant, severed head for eighty-seven years. This episode is a projection of what a world without conflict might be like, in opposition to the extreme state of conflict in the earlier part of the tale. But it comes with the foreknowledge that such a state of non-conflict is not sustainable in social reality, especially a medieval Welsh social reality populated by violently antagonistic, territorial rulers of both native Welsh and planted Norman descent.

The posited utopia thus feels fictive and mythic in its exclusion of external social contact and any description of disagreement within the group - for in social interaction there is always conflict that must be comprehended and rationalized. In Harlech, the Welsh veterans are overwhelmed by sensory pleasure as they listen to the sweet song of the birds of Rhiannon and imbibe the food and drink of the perpetual feast. After seven years in this uniform, blissful

Jung (1959: 150-1) would view Efnisien's remorseful self-sacrifice in accordance with his portrayal of the trickster as, in the end, a "saviour" figure. For Jung, the emergence of such a figure evidences the evolution from the unconscious and primitive trickster archetype to civilized psychological advancement in a "trend towards meaning" in which a seemingly nonsensical calamity has been "consciously understood." While I do not advocate Jung's evolutionary primitivism, a Žižekian reading of Efnisien corresponds with Jung's perception of a trend towards the inscription of meaning. Jarvis (2007: 75) also recognizes this trend but opts for a more literal reading, interpreting Efnisien's expression of remorse as evidence that he has emerged from a temporary period of mania. 
state, they proceed to Gwales where it is as though they enter a state of suspended consciousness. We are told: Ac yr a welsynt o ouut yn y gwyd, ac yr a gewssynt e hun, ny doy gof udunt wy dim, nac o hynny nac o alar yn y byt "And of all the sorrow they had themselves seen and suffered, they remembered none of it nor of any grief in the world" (Thomson 1961: 16; Davies 2007: 33). All memory of conflict must be erased in order to experience the sort of mythic, perfect pleasure that is incongruent with contentious social reality. The poignancy of the painful inrush of emotion upon the men's re-entry into the social world serves to underpin the inescapability of social unrest, trauma and distress. The narrative's recognition of the impossibility of utopia through the reassertion of pain affirms the social utility, in times of incomprehensible strife, of an Efnisien-like figure onto whom disruptive intent can be projected.

The Second Branch of the Mabinogi is a story with great resonance for an audience in that it concerns the tragic unpredictability of life. So, too, is the trickster - as he emerges in the character of Efnisien - something of a timeless figure, necessitated by the fragile nature of the social narrative. Efnisien makes his appearance in the story in order to introduce disruptive inconsistencies into the social order. As a device, he functions as a repository of ideological excess. $\mathrm{He}$ is the unknowable made manifest so that the audience can come to terms with the chaotic antagonism he represents, and he can be symbolically eliminated. His function is therefore vital, and yet it would be difficult to reach a consensus about the meaning of his actions, or indeed his motives for them. Efnisien - the trickster, the gwr anagneuedus "quarrelsome man" (Thomson 1961: 3; Davies 2007: 23) - needs little motivation and exists not to mean, but to be invested with meaning.

\section{REFERENCES}

Arnold, Matthew. 1867. On the Study of Celtic Literature. London: Smith, Elder, and Co.

Babcock-Abrahams, Barbara. 1975. “'A Tolerated Margin of Mess': The Trickster and His Tales Reconsidered," Journal of the Folklore Institute 11.3: 147-186.

Boas, Franz. 1898. Introduction to James Teit, Traditions of the Thompson Indians of British Columbia. Boston and New York: The American Folk-lore Society, 1-18.

Bollard, J. K. 1996a. "The Role of Myth and Tradition in the Four Branches of the Mabinogi," in: Charles W. Sullivan III (ed.) The Mabinogi: A Book of Essays. New York and London: Garland, 277-302.

Bollard, J.K. 1996b. "The Structure of the Four Branches of the Mabinogi," in: Charles W. Sullivan III (ed.) The Mabinogi: A Book of Essays. New York and London: Garland, 165-96.

Brinton, Daniel. 1868. The Myths of the New World: A Treatise on the Symbolism and Mythology of the Red Race of America. New York: Leypoldt and Holt.

Brinton, Daniel. 1890. "The Hero-God of the Algonkins as a Cheat and a Liar," Essays of an Americanist. Philadelphia: Porter and Coates, 130-134. 
Charles-Edwards, T. M. 1993. Early Irish and Welsh Kinship. New York: Clarendon.

Charles-Edwards, T.M. 2000. "Food, Drink, and Clothing in the Laws of Court," in: T. M. Charles-Edwards et al. (eds.) The Welsh King and His Court. Cardiff: University of Wales Press, 319-37.

Davies, R. R. 1987. The Age of Conquest: Wales 1063-1415. Oxford and New York: Oxford University Press.

Davies, Sioned (ed. and trans.). 2007. The Mabinogion. Oxford and New York: Oxford University Press.

Dougherty, Nancy J. and Jacqueline J. West. 2007. The Matrix and Meaning of Character: An Archetypal and Developmental Approach. London and New York: Routledge.

Dumézil, Georges. 1948. Loki. Paris: G.P. Maisonneuve.

Ellis, T.P. 1928. "Legal References, Terms and conceptions in the 'Mabinogion'," Y Cymmrodor 39: 86-148.

Emanuel, Hywel David (ed.). 1967. The Latin Texts of the Welsh Laws. Cardiff: University of Wales Press.

Ford, Patrick K. 1996. "Branwen: A Study of the Celtic Affinities," in: Charles W. Sullivan III (ed.) The Mabinogi: A Book of Essays. New York and London: Garland, 99-120.

Gilger, Brian C. 2015. "Ocular Trauma," in: Kim A. Sprayberry and N. Edward Robinson (eds.) Robinson's Current Therapy in Equine Medicine, $7^{\text {th }}$ edn. St. Louis, MO: Saunders, 39-44.

Gruffydd, W. J. (ed.). 1928. Math vab Mathonwy. Cardiff: University of Wales Press.

Hall, Alaric. 2001. "Gwŷr y Gogledd? Some Icelandic Analogues to Branwen Ferch Lŷr," Cambrian Medieval Celtic Studies 42: 27-50.

Jarvis, Branwen. 2007. "Yr Awdur a'i Gymeriadau: Y Portread o Efnisien yn Ail Gainc y Mabinogi," in: Jason Walford Davies (ed.) Gweledigaethau: Cyfrol Deyrnged yr Athro Gwyn Thomas. Llandybie: Cyhoeddiadau Barddas, 61-78.

Jenkins, Dafydd. 1997. "The Horse in the Welsh Law Texts", in Sioned Davies and Nerys Ann Jones (ed.) The Horse in Celtic Culture: Medieval Welsh Perspectives. Cardiff: University of Wales Press, 64-81.

Jenkins, Dafydd (ed. and trans.) 1986. The Law of Hywel Dda. Llandysul: Gomer Press.

Jenkins, Dafydd and Morfydd E. Owen (eds.). 1980. "Glossary," in: The Welsh Laws of Women. Cardiff: University of Wales Press, 187-221.

Jung, C. G. 1959. The Archetypes and the Collective Unconscious (trans. R. F. C. Hull). The Collected Works of C. J. Jung, vol. 9, part 1. Bollingen Series 20. New York: Bollingen Foundation, Inc.

Koepping, Klaus-Peter. 1985. "Absurdity and Hidden Truths: Cunning Intelligence and Grotesque Body Images as Manifestations of the Trickster," History of Religions 24.3: 191-214.

Lloyd, E. J. 1911a. "The Mabinogion as Literature," The Celtic Review 7.26 (May): 164-174.

Lloyd, E. J. 1911b. The Celtic Review 7.27 (Oct.): 220-248.

Mac Cana, Proinsias. 1958. Branwen, Daughter of Llŷr: A Study of the Irish Affinities and of the Composition of the Second Branch of the Mabinogi. Cardiff: University of Wales Press.

Meulder, Marcel. 2008. "Nisien et Efnisien: Couple Odinique ou Dioscurique?" Nuntius Antiquus 1: $141-158$.

McAll, Christopher. 1980. "The Normal Paradigm of a Woman's Life in the Irish and Welsh Texts," in: Dafydd Jenkins and Morfydd E. Owen (eds.), The Welsh Law of Women. Cardiff: University of Wales Press, 7-22. 
McKenna, Catherine. 2007. "The Colonization of Myth in Branwen Ferch Lŷr," in: Joseph Nagy (ed.), CSANA Yearbook 6: Myth in Celtic Literatures. Dublin: Four Courts Press, 105-119.

Nutt, Alfred. 1882. "Mabinogion Studies," The Folk-Lore Record 5: 1-32.

Owen, Morfydd E. 1980. "Shame and Reparation; Woman's Place in the Kin," in: Dafydd Jenkins and Morfydd E. Owen (eds.), The Welsh Law of Women. Cardiff: University of Wales Press, 40-68.

Rees, Brinley. 1975. Ceinciau'r Mabinogi. Bangor: Sili-wen.

Simmons, Victoria Gay. 2005. Tricksterism in Popular Traditions. [Unpublished Ph.D. dissertation, University of California, Los Angeles].

Stacey, Robin Chapman. 2000. "King, Queen, and Edling in the Laws of Court," in: T. M. Charles-Edwards et al. (eds.), The Welsh King and His Court. Cardiff: University of Wales Press, 29-62.

Thomson, Derick S. (ed.). 1961. Branwen Uerch Lyr. Medieval and Modern Welsh Series, vol. 2. Dublin: Dublin Institute for Advanced Studies.

Williams, Ifor (ed.). 1930. Pedeir Keinc y Mabinogi. Cardiff: University of Wales Press.

Žižek, Slavoj. 1992. Looking Awry: An Introduction to Jacques Lacan through Popular Culture. Cambridge, MA: The MIT Press.

Žižek, Slavoj. 1989. The Sublime Object of Ideology. London and New York: Verso. 